\title{
Thermogravimetric Experiment of Urea at Constant Temperatures
}

\author{
Neng Zhu ${ }^{1}$, Feng Qian ${ }^{1, *}$, Xiaowei Xu ${ }^{1}$, Mingda Wang ${ }^{2}$ and Qi Teng ${ }^{2}$ \\ 1 School of Automotive and Transportation Engineering, Wuhan University of Science and Technology, \\ Wuhan 430081, China; znqc@wust.edu.cn (N.Z.); Xiaowei.xu@wust.edu.cn (X.X.) \\ 2 Chinese Academy of Environmental Sciences, Beijing 100012, China; wangmingda@vecc-mee.org.cn (M.W.); \\ tengq@vecc.org.cn (Q.T.) \\ * Correspondence: feng.qian@wust.edu.cn; Tel.: +86-180-6206-0988
}

Citation: Zhu, N.; Qian, F;

Xu, X.; Wang, M.; Teng, Q.

Thermogravimetric Experiment of Urea at Constant Temperatures. Materials 2021, 14, 6190. https:// doi.org/10.3390/ma14206190

Academic Editor: Valentina

Migliorati

Received: 15 September 2021

Accepted: 14 October 2021

Published: 18 October 2021

Publisher's Note: MDPI stays neutral with regard to jurisdictional claims in published maps and institutional affiliations.

Copyright: (C) 2021 by the authors. Licensee MDPI, Basel, Switzerland. This article is an open access article distributed under the terms and conditions of the Creative Commons Attribution (CC BY) license (https:// creativecommons.org/licenses/by/ $4.0 /)$.

\begin{abstract}
There are still many unsolved mysteries in the thermal decomposition process of urea. This paper studied the thermal decomposition process of urea at constant temperatures by the thermal gravimetric-mass spectrometry analysis method. The results show that there are three obvious stages of mass loss during the thermal decomposition process of urea, which is closely related to the temperature. When the temperature was below $160^{\circ} \mathrm{C}$, urea decomposition almost did not occur, and molten urea evaporated slowly. When the temperature was between 180 and $200{ }^{\circ} \mathrm{C}$, the content of biuret, one of the by-products in the thermal decomposition of urea, reached a maximum. When the temperature was higher than $200^{\circ} \mathrm{C}$, the first stage of mass loss was completed quickly, and urea and biuret rapidly broke down. When the temperature was about $240{ }^{\circ} \mathrm{C}$, there were rarely urea and biuret in residual substance; however, the content of cyanuric acid was still rising. When the temperature was higher than $280^{\circ} \mathrm{C}$, there was a second stage of mass loss. In the second stage of mass loss, when the temperature was higher than $330^{\circ} \mathrm{C}$, mass decreased rapidly, which was mainly due to the decomposition of cyanuric acid. When the temperature was higher than $380^{\circ} \mathrm{C}$, the third stage of mass loss occurred. However, when the temperature was higher than $400{ }^{\circ} \mathrm{C}$, and after continuous heating was applied for a sufficiently long time, the residual mass was reduced to almost zero eventually.
\end{abstract}

Keywords: thermal decomposition; deposits; selective catalytic reduction; diesel engine

\section{Introduction}

Interest in the study of urea has continued to grow since urea was found by Roselle [1] in 1773. In 1828, German chemist Wohler [2] converted inorganic ammonium cyanate to organic urea by heating method for the first time, which, for the first time, broke the traditional idea that organics can only be obtained from organic compounds. The synthesis of urea has opened a prologue of artificial synthesis organics, and it is thought to be a pioneer in organic chemistry research. Nowadays, urea has been widely used in many fields such as the medical industry, agriculture, manufacture, and commerce and is closely related to human production and living. Even so, there are still many mysteries in the thermal decomposition process of urea.

At present, selective catalytic reduction (SCR), which uses urea water solution (UWS) as the reductant, is widely regarded as one of the most promising technologies to reduce $\mathrm{NO}_{x}$ emissions from diesel engines and to meet increasingly stringent emission regulation standards [3-5]. However, there are many problems derived from the urea decomposition process. One of them is that deposit formation on catalyst and inlet pipe surfaces blocks the pores and the active sites of catalyst, which decreases the durability of the SCR systems. Therefore, a better understanding of the urea decomposition process can lead to improvement in the SCR performance and overcome this shortcoming [6]. 
It is well known that urea starts to break down at about $150{ }^{\circ} \mathrm{C}$ and generates equimolar $\mathrm{NH}_{3}$ and $\mathrm{HNCO}$ (reaction (1)) [7-10]. HNCO is prone to hydrolysis (reaction (2)). However, in the process of urea pyrolysis, there will be multiple side reactions, and the generated by-products are closely related to the temperature. Schaber's research [11] showed that when the temperature was above $152{ }^{\circ} \mathrm{C}$, the decomposition of urea occurred (reaction (1)). At about $160^{\circ} \mathrm{C}, \mathrm{HNCO}$, the product of urea pyrolysis, reacted with the remaining urea to generate biuret (reaction (3)). At about $175^{\circ} \mathrm{C}$, cyanuric acid (reactions (4) and (5)) and ammelide (reaction (6)) began to generate. At about $250{ }^{\circ} \mathrm{C}$, the ammeline started to generate (reaction (7)). Thagard [12] dealt with the chemical analysis of the by-products formed by urea decomposition at about $150-200{ }^{\circ} \mathrm{C}$ in a dielectric barrier discharge (DBD). Recent studies [13-17] showed that we could obtain hydrogen by urea pyrolysis reaction, which was considered as a potential source of hydrogen/fuel cell power. Jenny [17] studied the thermal decomposition of urea and aqueous urea solutions in the presence of $18 \mathrm{wt} \%$ nickel on alumina. Steffen's research [18] observed and explained the phenomenon of liquefaction and resolidification of biuret in the temperature range of $193 \sim 230{ }^{\circ} \mathrm{C}$. In addition, Stradella [19], Carp [20], and Lundstrom [21] have also carried out related studies on urea pyrolysis. Furthermore, the kinetic analyses of the thermal decomposition reaction of urea and related by-product can be evaluated using thermogravimetric analysis [22,23]. However, in these studies, the thermal decomposition process of urea under constant temperatures condition is not described.

$$
\begin{gathered}
\text { Urea pyrolysis: }\left(\mathrm{H}_{2} \mathrm{~N}\right)_{2} \mathrm{CO} \rightarrow \mathrm{NH}_{3}+\mathrm{HNCO} \\
\text { HNCO hydrolysis: } \mathrm{HNCO}+\mathrm{H}_{2} \mathrm{O} \rightarrow \mathrm{NH}_{3}+\mathrm{CO}_{2} \\
\text { Generation of biuret: }\left(\mathrm{H}_{2} \mathrm{~N}\right)_{2} \mathrm{CO}+\mathrm{HNCO} \rightarrow\left(\mathrm{H}_{2} \mathrm{NCO}\right)_{2} \mathrm{NH} \\
\text { Generation of cyanuric acid: }\left(\mathrm{H}_{2} \mathrm{NCO}\right)_{2} \mathrm{NH}+\mathrm{HNCO} \rightarrow \mathrm{CYA}+\mathrm{NH}_{3} \\
\text { Generation of cyanuric acid: } 3 \mathrm{HNCO} \rightarrow \mathrm{CYA} \\
\text { Generation of ammelide: }(\mathrm{HNCO})_{3}+\mathrm{NH}_{3} \rightarrow \text { ammelide }+\mathrm{H}_{2} \mathrm{O} \\
\text { Generation of ammeline: ammelide }+\mathrm{NH}_{3} \rightarrow \text { ammeline }+\mathrm{H}_{2} \mathrm{O}
\end{gathered}
$$

SCR is a technology to deal with $\mathrm{NO}_{x}$ emission from diesel engines, and its reducing agent is ammonia gas produced by the decomposition of urea. In this process, undesired solid by-products, commonly known as deposits, are formed in the exhaust pipe. Deposits, in general, show in three places of the SCR system: interior part of urea injector, exhaust pipe wall, and catalyst entrance. Deposits on the exhaust pipe wall may decrease the utilization rate of urea. Concentration weakening of $\mathrm{NH}_{3}$, which reacts with $\mathrm{SCR}$, could lead to reducing the conversion efficiency of the SCR system. A considerable quantity of deposits may cause partial and even complete blockage of the exhaust pipe, increase exhaust backpressure, and thus influence the performance of the engine. Hence, in order to guarantee the normal operation of the SCR system and engine, addressing deposit-related problems on the exhaust pipe wall is very urgent.

In order to explore the underlying causes and influential factors in deposits' generation, scholars carried out numerous relevant studies [24,25]. Way [26] analyzed the composition of deposits. The outcome indicates deposits are composed of undecomposed urea (occupy 5 15\%), biuret (occupy 5 15\%), and CYA (occupy 70 95\%). Research by Zheng [27] indicates pipe wall temperature exerts a certain influence on the formation of deposits. Strots [28] conducted a study on the proportion of deposits in urea consumption under different exhaust temperatures and ambient temperatures, the results of which showed that the lower the exhaust temperature is, the larger the proportion of deposits will account for. $\mathrm{Xu}$ [29] researched the influence of exhaust temperature and catalyst types (iron zeolite and copper zeolite) on deposits production, the results of which showed that the lower the exhaust temperature is, the more easily the deposits form. 
The formation and decomposition of these by-products have a strong correlation with temperature. This was our motivation to systematically investigate the decomposition of urea at constant temperatures by performing TG experiments. Therefore, in this study, the thermal decomposition process of urea with continuous heating under constant temperatures was investigated utilizing the thermogravimetric (TG) analysis method, in parallel with detecting the evolved gases by mass spectrometry (MS). This research helps to solve the problem of deposits in diesel SCR systems.

\section{Materials and Methods}

The urea used in the experiments was produced by Tianjin Guangfu Technology Development Co. Ltd., and the purity was not less than $99 \%$. Urea was heated by a STA449F3 model synchronized thermal analyzer, produced by NETZSCH. In the process of heating, temperatures were controlled by programs, and urea mass loss could be measured. Usually, approximately $10 \mathrm{mg}$ samples of urea is put on the alumina crucible. Argon was the purging gas in the heating furnace, and the purging velocity was $40 \mathrm{~mL} / \mathrm{min}$. In addition, a QMS403C model quadrupole mass-spectrum analyzer was also used synchronously with the thermal analyzer to detect the escaping gas composition in the process of thermal decomposition of urea.

In this article, urea was heated from ambient temperature to $1000{ }^{\circ} \mathrm{C}$ with a heating rate of $10^{\circ} \mathrm{C}$ per minute. The thermogravimetric curve is shown in Figure 1 . In addition, urea was also heated from ambient temperature to different target temperatures, with the fastest heating rate of $40{ }^{\circ} \mathrm{C}$ per minute, then the apparatus maintained a constant temperature for a period of time until the residual mass was no longer change. Specifically, the constant temperatures were kept for $3 \mathrm{~h}$ when target temperatures were $140^{\circ} \mathrm{C}, 160^{\circ} \mathrm{C}$, and $280^{\circ} \mathrm{C}, 1 \mathrm{~h}$ when target temperatures were $180^{\circ} \mathrm{C}, 200^{\circ} \mathrm{C}$, and $240{ }^{\circ} \mathrm{C}$, and $40 \mathrm{~min}$ when target temperatures were $320^{\circ} \mathrm{C}, 360^{\circ} \mathrm{C}$, and $400{ }^{\circ} \mathrm{C}$. At different target temperatures, residual masses of temperature rising experiment and constant temperature experiment are shown in Table 1.

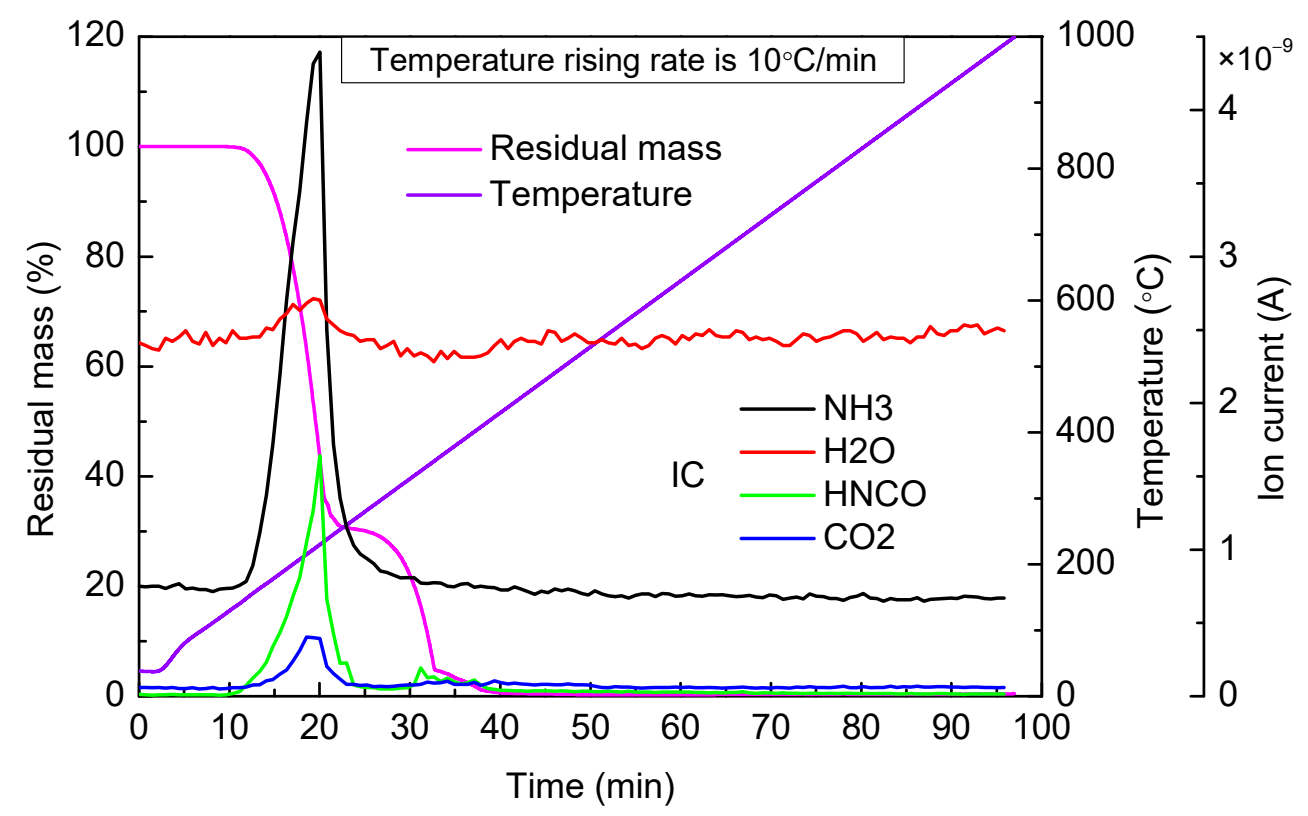

Figure 1. TG-MS results of urea in temperature-rising experiment. 
Table 1. Residual mass corresponding to different target temperatures.

\begin{tabular}{cccc}
\hline & \multicolumn{3}{c}{ Residual Mass (\%) } \\
\cline { 2 - 4 } Target Temp. $\left({ }^{\circ} \mathbf{C}\right)$ & Temp. Rising Expt. & \multicolumn{2}{c}{ Constant Temp. Expt. } \\
\cline { 2 - 4 } & & Initial Mass & Final Mass \\
\hline 140 & 99.79 & 99.66 & 26.87 \\
160 & 97.64 & 97.42 & 35.32 \\
180 & 90.99 & 96.74 & 36.53 \\
200 & 78.05 & 88.34 & 39.10 \\
240 & 34.22 & 58.60 & 28.35 \\
280 & 30.09 & 37.17 & 8.84 \\
320 & 25.18 & 22.85 & 7.12 \\
360 & 4.70 & 19.65 & 1.65 \\
400 & 1.97 & 3.74 & 0.14 \\
\hline
\end{tabular}

\section{Results}

\subsection{Temperature Rising Thermogravimetric Experiment}

Figure 1 shows the TG-MS results of urea in the temperature-rising experiment. From the thermogravimetric curve, we can infer that there were three obvious stages of mass loss in the urea pyrolysis process. The first stage of mass loss was between $140{ }^{\circ} \mathrm{C}$ to $250{ }^{\circ} \mathrm{C}$, and there was about $68.6 \%$ mass loss. The second stage concluded at about $360{ }^{\circ} \mathrm{C}$ and about $26.7 \%$ mass loss. The third concluded at about $410{ }^{\circ} \mathrm{C}$ and about $3.6 \%$ mass loss.

Based on mass spectrum curves in Figure 1, when the temperature reached urea melting point $133^{\circ} \mathrm{C}$, the ion current intensity of evolved gases, $\mathrm{NH}_{3}$ and $\mathrm{HNCO}$, increased slowly. This is due to the fact that after evaporation, molten urea decomposed in the process of entering the mass spectrograph through a capillary whose temperature was $280^{\circ} \mathrm{C}$ (reaction (1)). When the temperature was higher than $152{ }^{\circ} \mathrm{C}$, the ion current intensity of $\mathrm{NH}_{3}$ and $\mathrm{HNCO}$ began to increase noticeably, which suggested that urea started to decompose. Until about $230{ }^{\circ} \mathrm{C}$, the concentration of $\mathrm{NH}_{3}$ and $\mathrm{HNCO}$ was observed reaching a maximum value almost at the same time. It is obvious that the concentration of $\mathrm{HNCO}$ was far less than $\mathrm{NH}_{3}$, so it can be inferred that the generated $\mathrm{HNCO}$ was consumed partially through other reactions. Schaber [11] and Kleemann [30] also observed this phenomenon. At the same time, $\mathrm{CO}_{2}$ was observed to escape, which indicated that the hydrolysis reaction of HNCO might happen (reaction (2)). Kleemann's [30] research shows that $\mathrm{HNCO}$ is a very stable gas, and the hydrolysis reaction more likely occurs on the catalyst surface, so there are other reactions for the consumption of HNCO. When the temperature was higher than $160^{\circ} \mathrm{C}$, residual urea would react with $\mathrm{HNCO}$ to generate biuret (reaction (3)), and the biuret would react with $\mathrm{HNCO}$ to generate CYA (reaction (4)). However, the thermogravimetric curve of biuret showed that at about $190{ }^{\circ} \mathrm{C}$, biuret decomposed (reaction (8)) to generate $\mathrm{HNCO}$; therefore, we can infer that there must be other reactions for the consumption of HNCO. Based on the studies of our predecessors, the polymerization of $\mathrm{HNCO}$ to generate CYA is considered a reasonable reaction to explain the above phenomenon (reaction (5)). The ion current intensity of $\mathrm{H}_{2} \mathrm{O}$ increased because of the occurrence of reactions 6 and 7 . When the temperature reached about $265{ }^{\circ} \mathrm{C}$, the low concentration of $\mathrm{NH}_{3}$ and $\mathrm{HNCO}$ indicated that there were little urea and biuret in the residual material. Until $330^{\circ} \mathrm{C}$, the variation trend of the thermogravimetric curve was flat, and the concentration of $\mathrm{NH}_{3}$ and $\mathrm{HNCO}$ was still relatively low. When the temperature was between 330 and $360{ }^{\circ} \mathrm{C}$, the concentration of $\mathrm{HNCO}$ reached another peak value, which was caused by the rapid decomposition of cyanuric acid (reaction (9)). When the temperature was above $360^{\circ} \mathrm{C}$, cyanuric acid decomposed continually, and there was still a small amount of HNCO that continued to escape. From then on, ammelide, ammeline, and other by-products decomposed one after another.

$$
\text { Decomposition of biuret: }\left(\mathrm{H}_{2} \mathrm{NCO}\right)_{2} \mathrm{NH} \rightarrow\left(\mathrm{H}_{2} \mathrm{~N}\right)_{2} \mathrm{CO}+\mathrm{HNCO}
$$




\subsection{Thermogravimetric Experiments at Constant Temperatures}

Given that the pyrolysis process of urea has a close relationship with temperature, in this paper, nine target temperatures between 140 and $400{ }^{\circ} \mathrm{C}$ were selected to carry out the thermogravimetric experiments.

When the targeted temperature was $140^{\circ} \mathrm{C}$ (Figure 2), urea mass decreased slowly. As the temperature was not enough high for the decomposition of urea, the slow evaporation of molten urea was the reason for mass loss. As can be seen from the mass spectrum curve, a small amount of $\mathrm{NH}_{3}$ and $\mathrm{HNCO}$ was observed to escape, which was because after evaporation, molten urea decomposed in the process of entering the mass spectrograph through a capillary whose temperature was $280^{\circ} \mathrm{C}$. After $180 \mathrm{~min}$ of continuous heating, urea mass was no longer reduced, and the final residual mass accounted for $26.87 \%$ of the total mass. Urea mass did not decrease to zero eventually, which indicated that under this temperature, urea would slowly turn to be other substances.

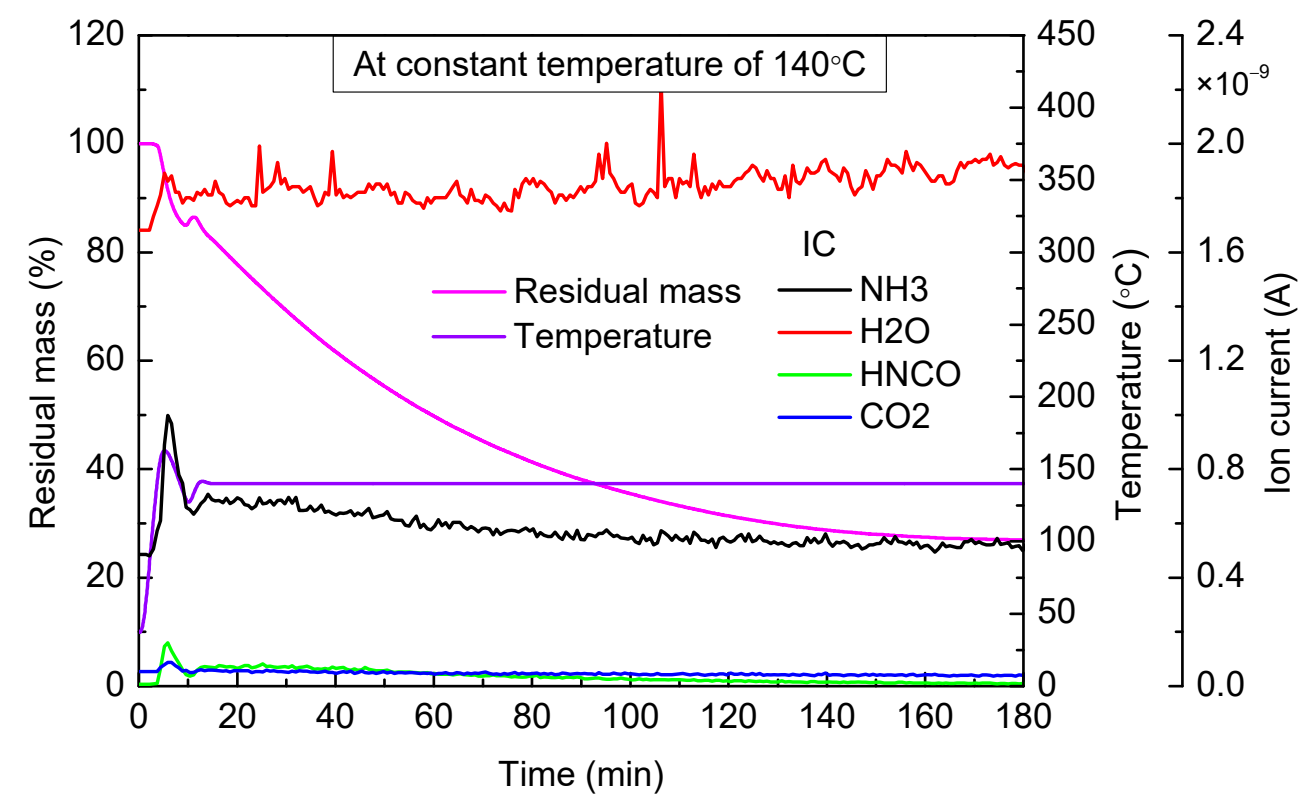

Figure 2. TG-MS results of urea at constant temperature of $140{ }^{\circ} \mathrm{C}$.

When the targeted temperature was $160^{\circ} \mathrm{C}$ (Figure 3), urea mass still declined slowly. Although it reached the urea pyrolysis temperature, the ion current intensity of $\mathrm{NH}_{3}$ was still low and close to the case of $140{ }^{\circ} \mathrm{C}$. The above phenomenon indicated that the urea pyrolysis rate was slow in this case, and evaporation of urea was still the main reason for weight loss. In addition, we can see that the ion current intensity of HNCO in the case of $160{ }^{\circ} \mathrm{C}$ was lower than that of $140{ }^{\circ} \mathrm{C}$, which suggested that when the targeted temperature was $160{ }^{\circ} \mathrm{C}$, the polymerization reaction of $\mathrm{HNCO}$ occurred. After heating continuously for $80 \mathrm{~min}$, urea mass was no longer reduced, and the final residual mass accounted for $35.32 \%$ of the total mass.

When the targeted temperature was $180{ }^{\circ} \mathrm{C}$ (Figure 4), the variation trend of urea mass was similar to that in the former cases. The only difference was that the required time to reach a steady state was shortened. Observed from the result of mass spectrometry, ion current intensity of $\mathrm{NH}_{3}$ and $\mathrm{HNCO}$ significantly increased, which indicated that urea pyrolysis at this temperature was the main reason for weight loss. After heating continuously for $25 \mathrm{~min}$, remnants reached a steady state, and the final residual mass accounted for $36.53 \%$ of the total mass. 


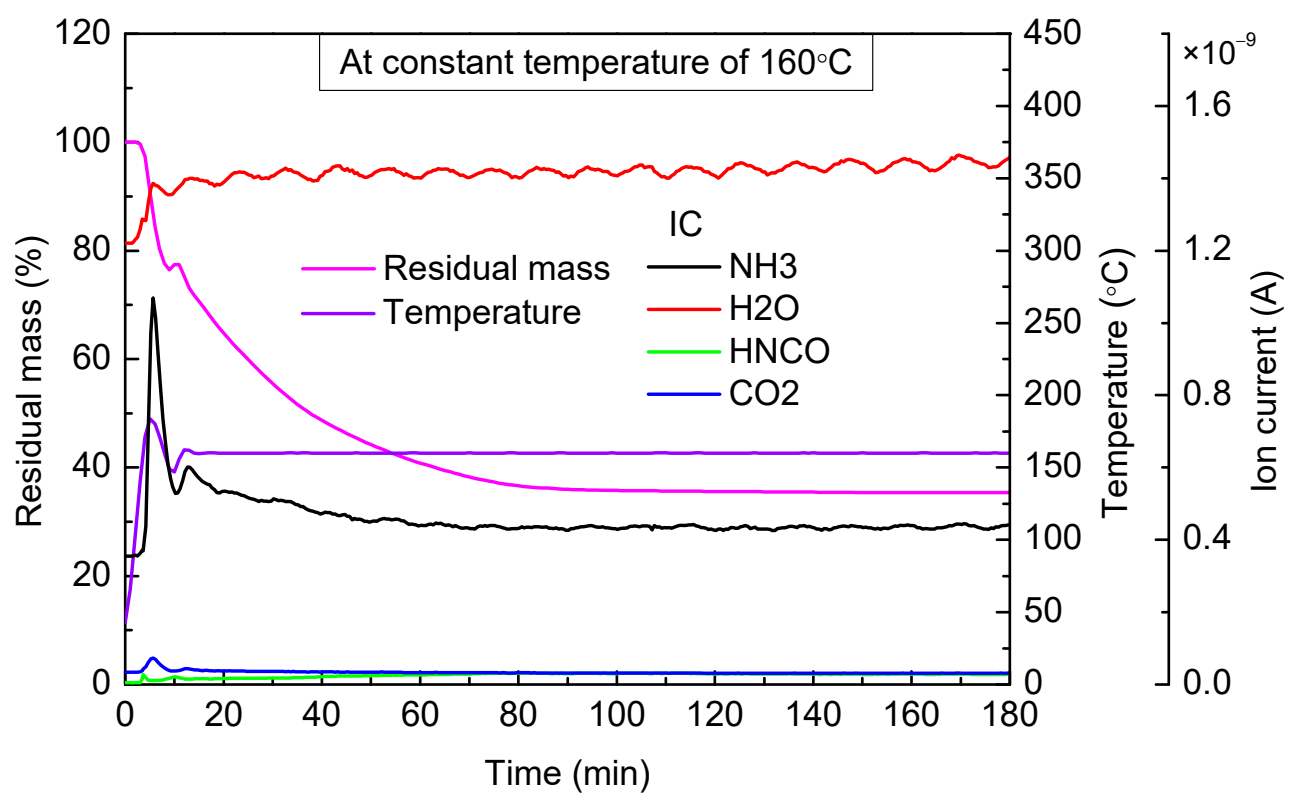

Figure 3. TG-MS results of urea at constant temperature of $160^{\circ} \mathrm{C}$.

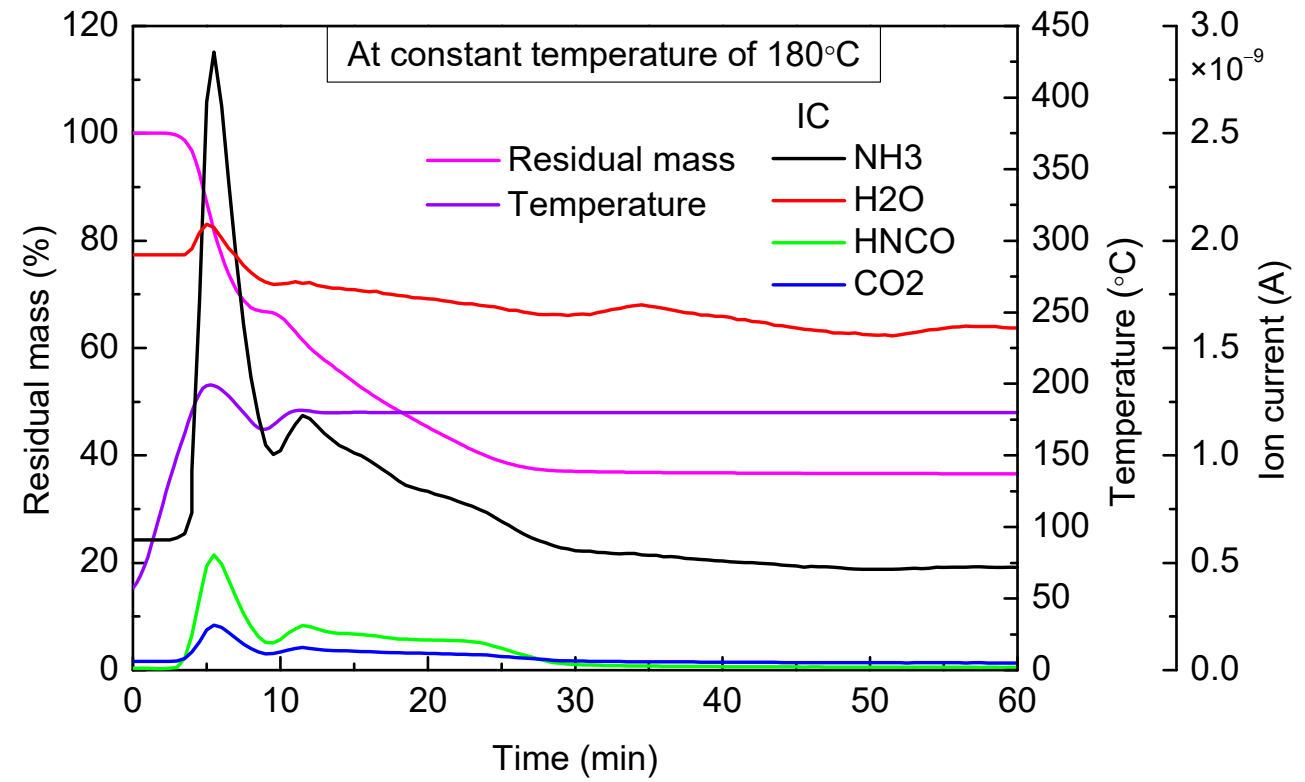

Figure 4. TG-MS results of urea at constant temperature of $180{ }^{\circ} \mathrm{C}$.

When the targeted temperature was $200{ }^{\circ} \mathrm{C}$ (Figure 5), there were two stages of mass loss in the urea pyrolysis process. The first stage lasted for about $5 \mathrm{~min}$. There was a large amount of $\mathrm{NH}_{3}$ and $\mathrm{HNCO}$ escaping and residual mass, which accounted for $47.5 \%$ of the total mass. This mass loss was mainly caused by urea pyrolysis. In the second stage, residual mass declined slowly. After continuously heating for $30 \mathrm{~min}$, mass loss was about $6.5 \%$. The melting point of biuret is $190^{\circ} \mathrm{C}$, and its thermal decomposition products are urea and $\mathrm{HNCO}$ (Equation (8)). From the mass spectrum curve, it can be observed that the concentration of $\mathrm{NH}_{3}$ and $\mathrm{HNCO}$ was extremely low; thus, the evaporation of biuret was the main cause of mass loss in the second stage. 


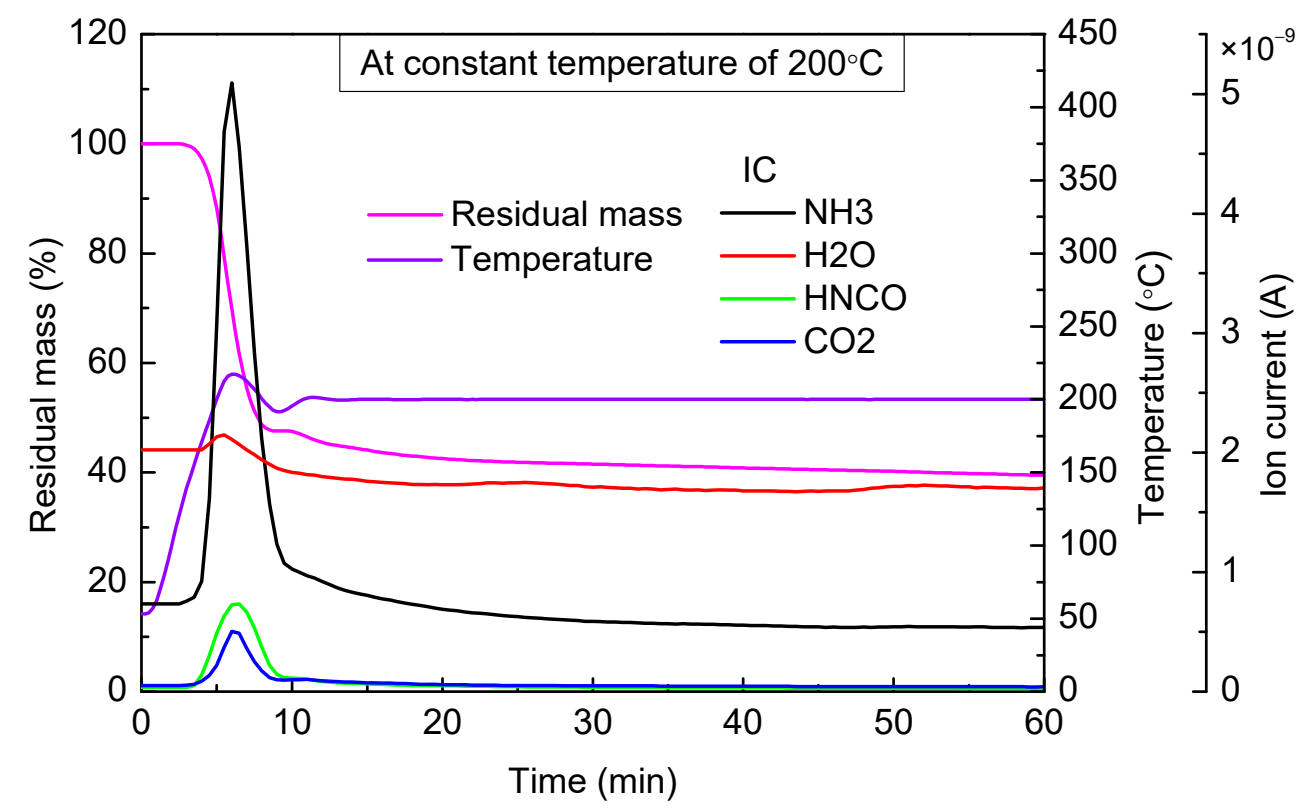

Figure 5. TG-MS results of urea at constant temperature of $200^{\circ} \mathrm{C}$.

Based on the above analyses, we can infer that when the temperature was below $200{ }^{\circ} \mathrm{C}$, with temperature increasing, the duration of the first mass loss stage in the urea pyrolysis process became shorter, and the final residual mass increased. Between 140 and $160{ }^{\circ} \mathrm{C}$, urea pyrolysis hardly occurred, and evaporation of molten urea was the main feature in this temperature range. Between 160 and $180{ }^{\circ} \mathrm{C}$, urea started to decompose, and the higher the temperature was, the shorter was the time to reach a steady state (i.e., residual mass no longer changed), and the faster was the urea pyrolysis rate. Even though the urea pyrolysis rate was higher in the case of $180^{\circ} \mathrm{C}$, the residual mass was still about $1 \%$ higher than the case of $160^{\circ} \mathrm{C}$, which suggested that the formation rate of by-products also increased. Between 180 and $200{ }^{\circ} \mathrm{C}$, urea decomposed quickly, and the first stage of mass loss was completed in a short time. However, at $200{ }^{\circ} \mathrm{C}$, the slow evaporation of biuret led to the second stage of mass loss, so the amount of biuret in the residual material reached a maximum in the temperature range of $180 \sim 200{ }^{\circ} \mathrm{C}$.

When the targeted temperature was $240^{\circ} \mathrm{C}$ (Figure 6), there was only one stage of mass loss, and the escaping amount of $\mathrm{NH}_{3}$ and $\mathrm{HNCO}$ increased rapidly. Hence, a large amount of biuret decomposed at this temperature. The process of mass loss was accomplished within $5 \mathrm{~min}$, which suggested that the biuret pyrolysis rate was high. Finally, residual mass accounted for $28.3 \%$ of the total mass. There was little urea and biuret in the residual material, and the main ingredient was cyanuric acid.

When the targeted temperature was $280{ }^{\circ} \mathrm{C}$ (Figure 7), the two stages of mass loss were similar to the case of $20{ }^{\circ} \mathrm{C}$. The first stage of mass loss was completed in the process of rapid temperature rising, and the residual mass decreased from $100 \%$ to $36 \%$ of the total mass within $4 \mathrm{~min}$. Mass spectrometry results showed that a large amount of $\mathrm{NH}_{3}$ and $\mathrm{HNCO}$ escaped. The main ingredient was cyanuric acid in residual material at the end of the first stage. The second stage of mass loss lasted for about $70 \mathrm{~min}$, and the mass loss was about $25 \%$. Based on the mass spectrometry results, HNCO was not visibly detected, which suggested that under this temperature, cyanuric acid could hardly decompose. The second stage of mass loss was mainly caused by the sublimation of cyanuric acid and other by-products. Even at $280^{\circ} \mathrm{C}$, after a sufficiently long time of heating, the residual mass still did not reach zero, and the final residual mass accounted for $8.1 \%$ of the total mass. 


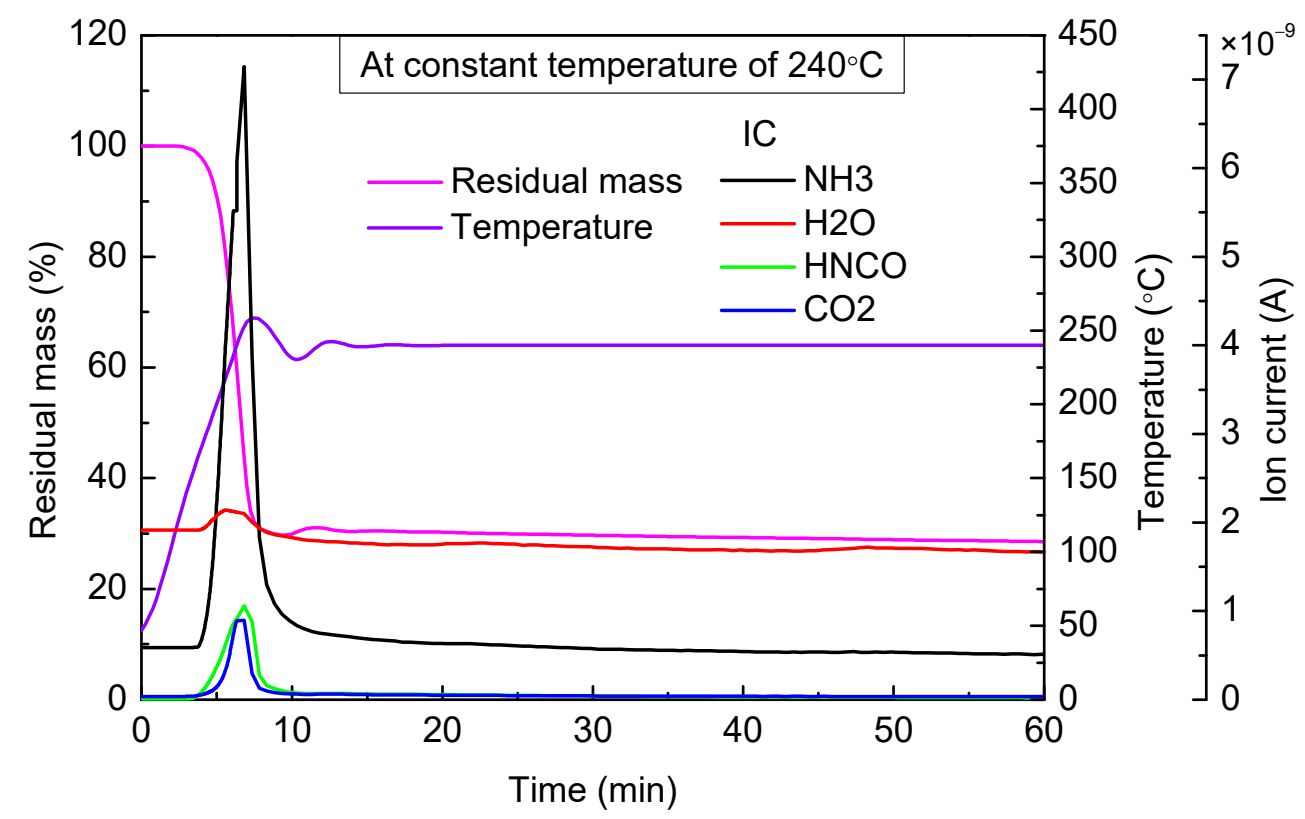

Figure 6. TG-MS results of urea at constant temperature of $240{ }^{\circ} \mathrm{C}$.

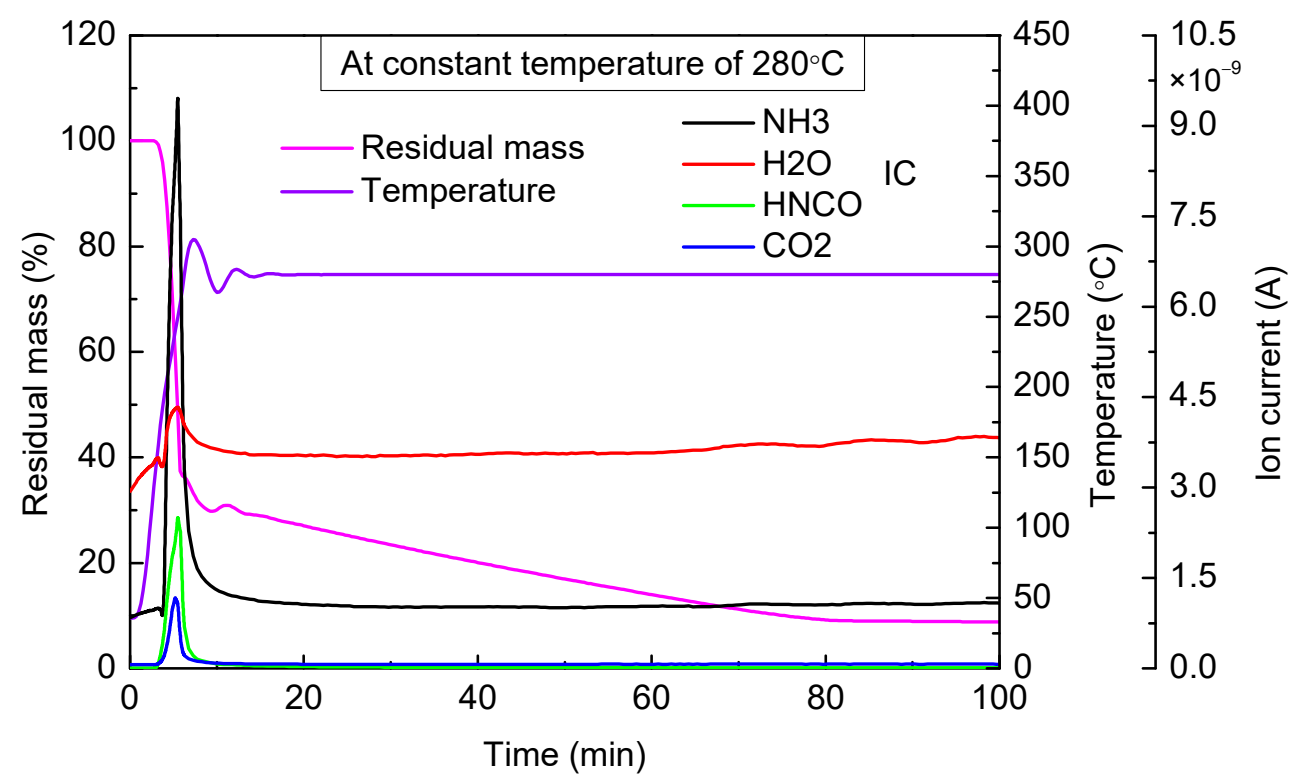

Figure 7. TG-MS results of urea at constant temperature of $280^{\circ} \mathrm{C}$.

Based on the above analyses, we can see that when the temperature was above $240{ }^{\circ} \mathrm{C}$, there was little urea and biuret in the residual material, and the main ingredient in the residual material was cyanuric acid. Compared with the case of $240^{\circ} \mathrm{C}$, it was obvious that the residual mass at the end of the first stage was more in the case of $280^{\circ} \mathrm{C}$, which indicated that the generation of cyanuric acid increased in the temperature range of $240 \sim 280^{\circ} \mathrm{C}$.

When the targeted temperature was $320^{\circ} \mathrm{C}$ (Figure 8), $360^{\circ} \mathrm{C}$ (Figure 9), and $400{ }^{\circ} \mathrm{C}$ (Figure 10), as can be observed, there were two stages of rapid mass loss on the thermogravimetric curve. The first stages of mass loss were all completed before $280{ }^{\circ} \mathrm{C}$, and the heating rate was high enough; therefore, in the three experiments, thermogravimetric curves in the first stages of mass loss basically coincided. At the end of the first stage of mass loss, the residual mass in three experiments, respectively, accounted for $30.43 \%$, $33.35 \%$, and $33.19 \%$ of the total mass. As can be seen from the results of mass spectrometry, in all these three experiments, there was a large amount of $\mathrm{NH}_{3}$ and $\mathrm{HNCO}$ escaping in 
the first stage of mass loss. The escaping amount was almost the same, and the peak value appeared near $250^{\circ} \mathrm{C}$.

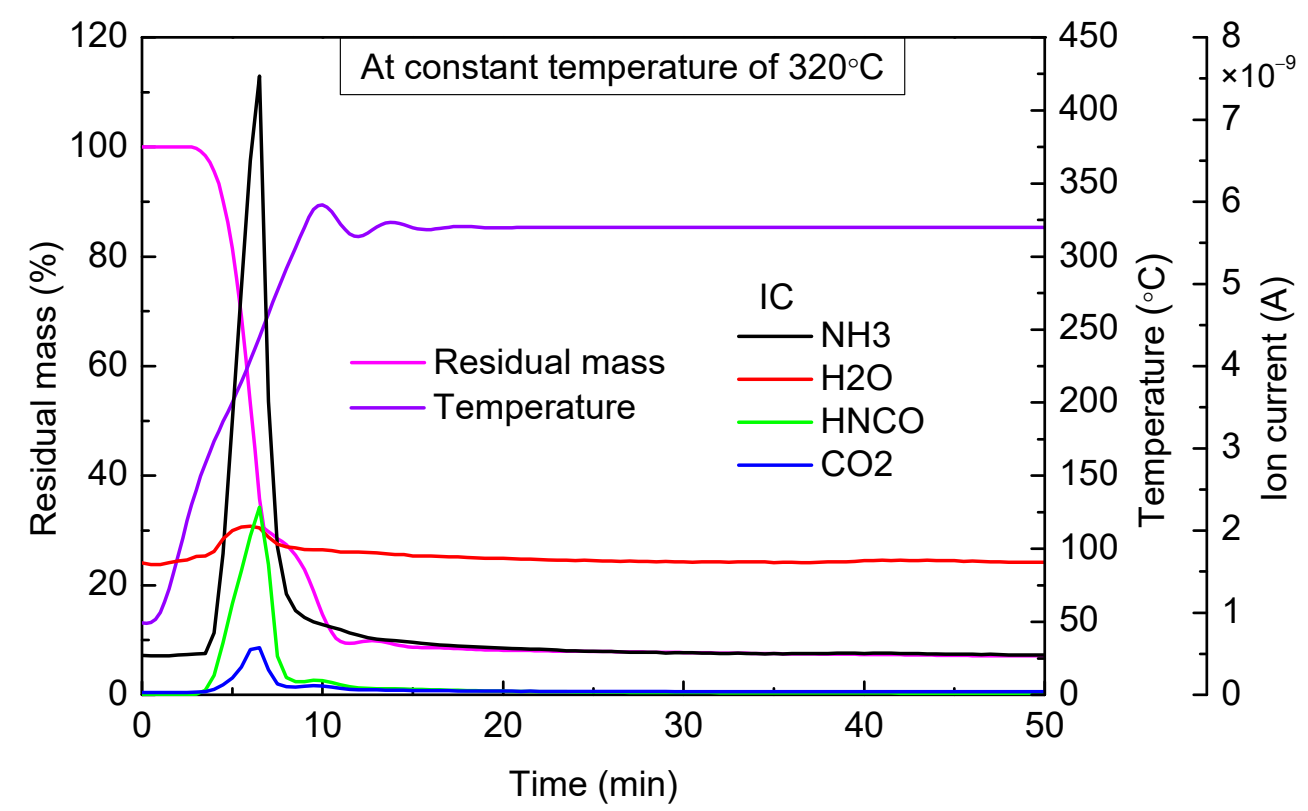

Figure 8. TG-MS results of urea at constant temperature of $320^{\circ} \mathrm{C}$.

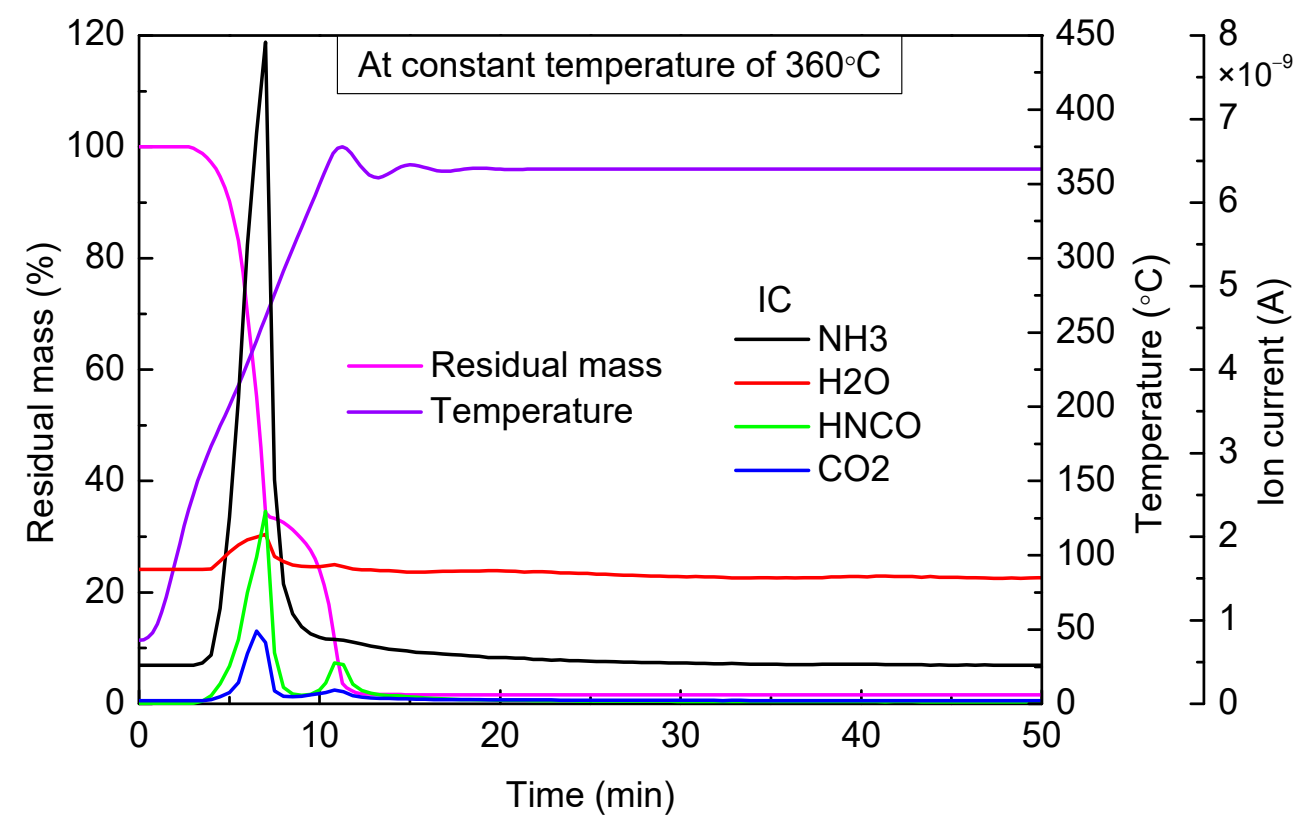

Figure 9. TG-MS results of urea at constant temperature of $360^{\circ} \mathrm{C}$.

Based on the above conclusions, at the end of the first stage of mass loss, almost no urea and biuret were contained in residual material, and the main ingredient was cyanuric acid. Therefore, the second stage of mass loss was mainly the decomposition process of cyanuric acid.

Compared with the cases of $360^{\circ} \mathrm{C}$ and $400{ }^{\circ} \mathrm{C}$, when the constant temperature was $320^{\circ} \mathrm{C}$, the thermogravimetric curve decreased relatively gently in the second stage of mass loss, and there was also an inconspicuous emergence of HNCO escaping observed from the mass spectrometry results, which indicated that cyanuric acid pyrolysis rate was low. When the constant temperatures were $360^{\circ} \mathrm{C}$ and $400{ }^{\circ} \mathrm{C}$, an obvious mass loss was 
observed, and HNCO started to escape when the temperature reached $330{ }^{\circ} \mathrm{C}$. Therefore, when the temperature was higher than $330^{\circ} \mathrm{C}$, cyanuric acid began to decompose rapidly.

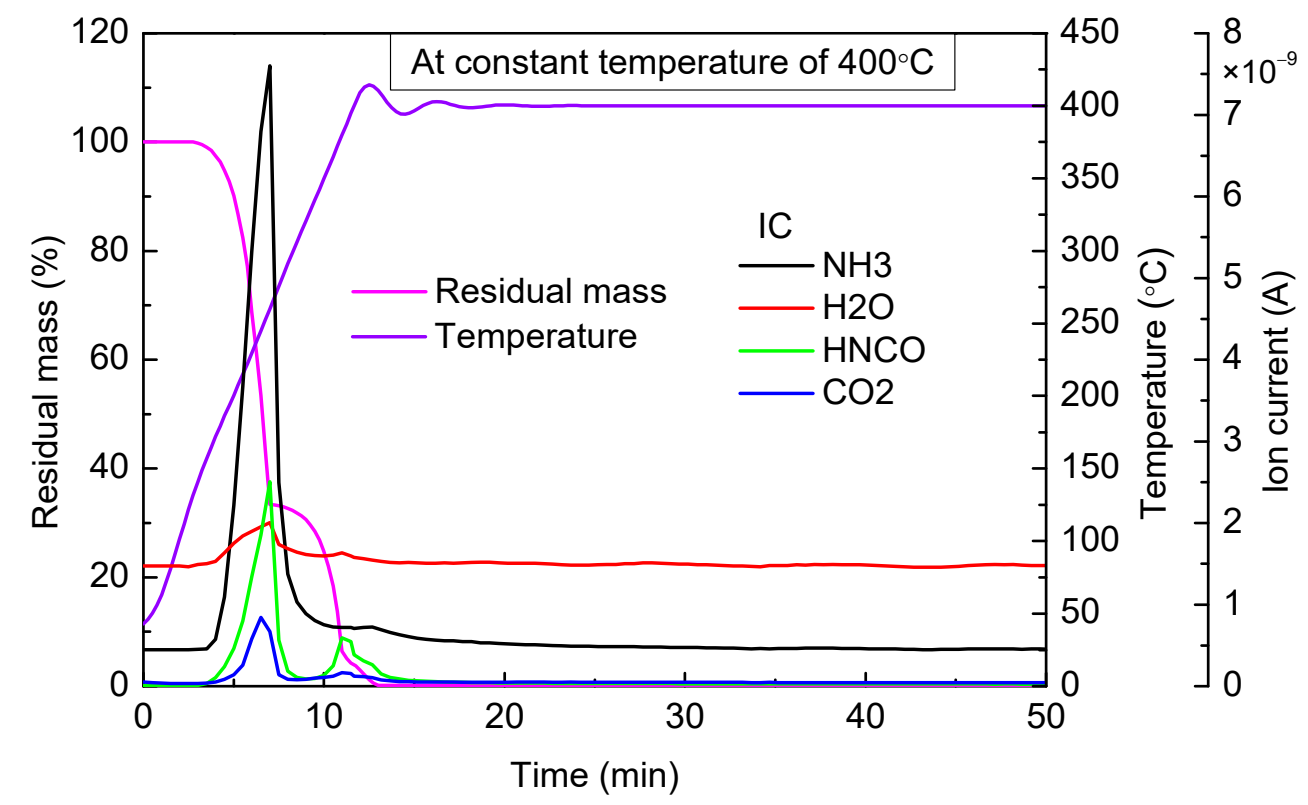

Figure 10. TG-MS results of urea at constant temperature of $400{ }^{\circ} \mathrm{C}$.

In addition, when the constant temperature was $400{ }^{\circ} \mathrm{C}$, a third stage of mass loss appeared. As can be seen from the thermogravimetric curve, the third stage of mass loss began when the temperature was higher than $380{ }^{\circ} \mathrm{C}$, and the final residual mass was almost zero (accounted for $0.14 \%$ of the total mass).

\section{Discussion}

The residual mass is closely related to the heating rate. When achieving the same targeted temperature, the slower the heating rate is, the longer is the continuous heating time of the urea sample, and the more complete is the thermal decomposition process, resulting in less residual mass. As shown in this paper, the pyrolysis process of urea at constant temperature for a long enough time was described in detail. The experimental results of urea-related deposit in the SCR system of diesel engines were explained from the perspective of the pyrolysis mechanism. Furthermore, research in the literature was supported.

When the SCR system operated below $200{ }^{\circ} \mathrm{C}$ for a long time, it was prone to form deposits such as biuret and lead to reducing the conversion efficiency of the SCR system. We could infer that the $\mathrm{NO}_{x}$ conversion efficiency was no more than $65 \%$ through the residual mass. Strots' research [28] showed that it was likely to form deposits when the exhaust temperature was lower than $200{ }^{\circ} \mathrm{C}$. Under the above condition, there were about $25 \sim 65 \mathrm{wt} \%$ of urea converting to the deposits.

When the SCR system operated below $300^{\circ} \mathrm{C}$, there was still a risk of forming deposits of CYA, which was more difficult to remove. Xu's research [29] showed that there were deposits formed, and the whole catalyst was almost blocked when the temperature of the SCR catalyst was $250^{\circ} \mathrm{C}$.

When the SCR system operated above $330^{\circ} \mathrm{C}$ for a period of time, the existing deposits were able to be eliminated. Strots' research showed that there was only less than $1 \mathrm{wt} \%$ of urea converting to the deposits when the exhaust temperature was achieving $350^{\circ} \mathrm{C}$. Xu's research showed that there was no deposit forming on the catalyst when the temperature of the SCR catalyst was $350^{\circ} \mathrm{C}$.

To summarize, the results of this paper could provide a theoretical basis to solve the problem of urea-related deposits for the SCR system. 


\section{Conclusions}

The urea pyrolysis process with the temperature rising at a certain heating rate has been studied by many researchers. In this paper, a temperature-rising thermogravimetric experiment of urea was carried out, and the mass loss of urea under different temperatures was observed to be similar to the results of predecessors. The urea pyrolysis process has a close relationship with the temperature, so thermogravimetric experiments of urea at constant temperatures were also studied in this paper.

When the targeted temperature was between 140 and $180^{\circ} \mathrm{C}$, urea mass reduced very slowly. If the heating rate was high enough, there would barely be any mass loss. If urea remained in the range of $140 \sim 180{ }^{\circ} \mathrm{C}$ for a long time, the final residual mass accounted for about $27 \sim 37 \%$ of the total mass. In addition, when the targeted temperature was between 140 and $160^{\circ} \mathrm{C}$, urea hardly decomposed, so evaporation of molten urea was the main reason for mass loss. When the targeted temperature was between 160 and $180^{\circ} \mathrm{C}$, urea began to decompose slowly. With the temperature increasing, the urea pyrolysis rate increased gradually, and the generation of by-products also increased at the same time.

When the targeted temperature was between 180 and $200^{\circ} \mathrm{C}$, urea began to decompose rapidly, and the amount of biuret in the residual material reached its maximum when the temperature was in the range of $180 \sim 200{ }^{\circ} \mathrm{C}$. When the targeted temperature was between 200 and $240{ }^{\circ} \mathrm{C}$, biuret began to decompose rapidly. If urea stayed in this temperature for enough long time, the residual mass finally accounted for about $28 \sim 39 \%$ of the total mass.

When the targeted temperature was between 240 and $280{ }^{\circ} \mathrm{C}$, there was a rapid decline in mass during the first stage, and this process was completed within $5 \mathrm{~min}$. The amount of cyanuric acid in the residual material gradually rose, and little urea and biuret were contained in the residual material. After keeping the temperature for a sufficiently long time, eventually, the residual by-products accounted for about $9 \sim 28 \%$ of the total mass.

When the targeted temperature was between 320 and $400{ }^{\circ} \mathrm{C}$, after the first stage of mass loss, residual mass accounted for about $30 \%$ of the total mass. After keeping the temperature for a sufficiently long time, residual material was less than $7 \%$ of the total mass in this temperature range.

The urea pyrolysis process has three obvious stages of mass loss. When the temperature was above $200^{\circ} \mathrm{C}$, the first stage of mass loss was completed quickly and basically finished before the temperature reached $280^{\circ} \mathrm{C}$. When the targeted temperature was above $330^{\circ} \mathrm{C}$, there was a rapid decline in mass during the second stage of mass loss. When the temperature was above $380^{\circ} \mathrm{C}$, there was a third stage of mass loss. When the temperature was above $400{ }^{\circ} \mathrm{C}$, residual mass eventually decreased to almost zero after continuous heating for a sufficiently long time.

Author Contributions: Experimental organization, N.Z.; data curation, F.Q.; review and suggestions, X.X.; writing-review and editing, M.W. and Q.T. All authors have read and agreed to the published version of the manuscript.

Funding: This research was funded by the National Natural Science Foundation of China (No. 51679176).

Institutional Review Board Statement: Not applicable.

Informed Consent Statement: Not applicable.

Data Availability Statement: Not applicable.

Acknowledgments: The authors appreciate the support of the School of Automotive and Transportation Engineering (Wuhan University of Science and Technology) and the Wuhan University of Technology.

Conflicts of Interest: The authors declare no conflict of interest. 


\section{References}

1. Frederick, K.; Phyllis, M.S. Urea in the history of organic chemistry. J. Chem. Educ. (Am. Chem. Soc.) 1956, 33, 452-459.

2. Shorter, J. The conversion of ammonium cyanate into urea-A saga in reaction mechanics. Chem. Soc. Rev. 1978, 7, 1-14. [CrossRef]

3. Tan, F. Developing and Simulation Research of Urea-SCR System Chemical Model of Diesel Engine. Master's Thesis, Wuhan University of Technology, Wuhan, China, 2013.

4. Haoyu, W. Design and Optimization of Urea-SCR System Reductant Supply Compensation Strategy for Diesel Engines. Master's Thesis, Wuhan University of Technology, Wuhan, China, 2013.

5. Johnson, T. Vehicular Emissions in Review. SAE Int. J. Engines 2013, 6, 699-715. [CrossRef]

6. Hongyi, D.; Shijin, S.; Jianxin, W. Effect of Urea Thermal Decomposition on Diesel $\mathrm{NO}_{x}$-SCR Aftertreatment Systems; SAE Technical Paper 2008-01-1544; SAE International: Pittsburgh, PA, USA, 2008. [CrossRef]

7. Scott Sluder, C.; Storey, J.; Lewis, S.; Lewis, L. Low Temperature Urea Decomposition and SCR Performance; SAE Technical Paper 2005-01-1858; SAE International: Pittsburgh, PA, USA, 2005. [CrossRef]

8. Koebel, M.; Elsener, M.; Kleemann, M. Urea-SCR: A promising technique to reduce $\mathrm{NO}_{x}$ emissions from automotive diesel engines. Catal. Today 2000, 59, 335-345. [CrossRef]

9. Gaia, P.; Martin, E.; Oliver, K. Influence of $\mathrm{NO}_{2}$ on the hydrolysis of isocyanic acid over $\mathrm{TiO}_{2}$. Appl. Catal. B Environ. 2006, 65, 169-174.

10. Noel, W.C.; Dean, C.C.; Andrew, D.C.; Irene, O.Y.; Atsushi, S. Formation and reactions of isocyanic acid during the catalytic reduction of nitrogen oxides. Top. Top. Catal. 2000, 10, 13-20.

11. Peter, M.S.; James, C.; Steven, H.; Daniel, T.; Bill, A.; Jonathan, B. Thermal decomposition (pyrolysis) of urea in an open reaction vessel. Thermochim. Acta 2004, 424, 131-142.

12. Thagard, S.M.; Mihalcioiu, A.; Takashima, K.; Mizuno, A. Analysis of the by-products in the ammonia production from urea by dielectric barrier discharge. IEEE Trans. Plasma Sci. 2009, 37, 444-448. [CrossRef]

13. Boggs, B.; King, R.; Botte, G. Urea electrolysis: Direct hydrogen production from urine. Chem. Commun.-R. Soc. Chem. 2009, 32, 4859-4861. [CrossRef]

14. Lan, R.; Tao, S.; Irvine, J. A direct urea fuel cell-power from fertiliser and waste. Energy Environ. Sci. 2010, 3, 438-441. [CrossRef]

15. Andrew, N.R.; Gavin, L.R.; Lea-Langton, A.R.; Valerie, D. Hydrogen from urea-water and ammonia-water solutions. Appl. Catal. B Environ. 2011, 106, 304-315.

16. Rollinson, A.N.; Jones, J.; Dupont, V.; Twigg, M.V. Urea as a hydrogen carrier: A perspective on its potential for safe, sustainable and long-term energy supply. Energy Environ. Sci. 2011, 4, 1216-1244. [CrossRef]

17. Jenny, M.J.; Andrew, N.R. Thermogravimetric evolved gas analysis of urea and urea solutions with nickel alumina catalyst. Thermochim. Acta 2013, 565, 39-45.

18. Tischer, S.; Brnhorst, M.; Amsler, J.; Schoch, G.; Deutschmann, O. Thermodynamics and reaction mechanism of urea decomposition. Phys. Chem. Chem. Phys. 2019, 21, 16785-16797. [CrossRef]

19. Stradella, L.; Argentero, M. A study of the thermal decomposition of urea, of related compounds and thiourea using DSC and TG-EGA. Thermochim. Acta 1993, 219, 315-323. [CrossRef]

20. Carp, O. Considerations on the thermal decomposition of urea. Rev. Roum. Chim. 2001, 46, 735-740.

21. Lundström, A.; Andersson, B.; Olsson, L. Urea thermolysis studied under flow reactor conditions using DSC and FT-IR. Chem. Eng. J. 2009, 150, 544-550. [CrossRef]

22. Rasim, A.; Karol, W.; Georg, M.; Abel, M.; Abdulsaid, A.; Ralf, Z.; Elvin, A.; Szczepan, Z. Effect of functional groups on the thermal degradation of phosphorus- and phosphorus/nitrogen-containing functional polymers. J. Therm. Anal. Calorim. 2017, 130, 799-812.

23. Mateusz, J.; Sławomir, S. Synthesis, characterization and thermal properties of T8 type amido-poss with p-halophenyl end-group. J. Organomet. Chem. 2017, 847, 173-183.

24. Munnannur, A.; Chiruta, M.; Liu, Z. Thermal and Fluid Dynamic Considerations in Aftertreatment System Design for SCR Solid Deposit Mitigation; SAE Technical Paper 2012-01-1287; SAE International: Pittsburgh, PA, USA, 2012. [CrossRef]

25. Chen, Y.; Lv, L.; Shen, J. Study on Deposit Formation for Urea Injector Based on a Detailed Deposit Model. Chin. Intern. Combust. Engine Eng. 2015, 36, 6-10.

26. Way, P.; Viswanathan, K.; Preethi, P.; Gilb, A.; Zambon, N.; Blaisdell, J. SCR Performance Optimization Through Advancements in Aftertreatment Packaging; SAE Technical Paper 2009-01-0633; SAE International: Pittsburgh, PA, USA, 2009. [CrossRef]

27. Zheng, G.; Fila, A.; Kotrba, A.; Floyd, R. Investigation of Urea Deposits in Urea SCR Systems for Medium and Heavy Duty Trucks; SAE Technical Paper 2010-01-1941; SAE International: Pittsburgh, PA, USA, 2010. [CrossRef]

28. Strots, V.O.; Santhanam, S.; Adelman, B.J.; Griffin, G.A.; Derybowski, E.M. Deposit Formation in Urea-SCR Systems. SAE Int. J. Fuels Lubr. 2010, 2, 283-289. [CrossRef]

29. Xu, L.; Watkins, W.; Snow, R.; Graham, G.; McCabe, R.; Lambert, C.; Carter, R.O. Laboratory and Engine Study of Urea-Related Deposits in Diesel Urea-SCR After-Treatment Systems; SAE Technical Paper 2007-01-1582; SAE International: Pittsburgh, PA, USA, 2007. [CrossRef]

30. Kleemann, M.; Elsener, M.; Koebel, M.; Wokaun, A. Hydrolysis of Isocyanic Acid on SCR Catalysts. Ind. Eng. Chem. Res. 2000, 39, 4120-4126. [CrossRef] 